\title{
Relationship of Blood Group Type and SARS-CoV-2 Infection: Experience in A Peripheral Military Hospital
}

\author{
MS BADSHA ${ }^{a}$, MMR KHAN ${ }^{b}$, SMB UDDIN ${ }^{c}$, K NESA $^{\mathrm{d}}$
}

\begin{abstract}
:
Introduction: Clinical studies have shown that advanced age and chronic diseases increase the risk of infection. Different studies have found blood groups are also a determining factor of severity. However, in Bangladesh it is yet to have any clinical pattern in this respect. The aim of this study is to find out whether there exists a relationship between the blood groups of the patients and risk of SARS-CoV-2 infection.
\end{abstract}

Methods: The study is a retrospective cohort study. It included all hospitalized RT-PCR confirmed COVID-19 patients in Combined Military Hospital (CMH) Barishal. We included both genders and people who are older than 14 years of age. The study was conducted during the period between 4th June and 3rd August, 2020. In this period total 556 individuals reported and tested for SARS-CoV-2 where COVID +ve patients are served as patient group and COVID-ve patients are served as the controls.

Results: Our sample consists of 185 patients; we found a percentage distribution of $34.6 \%, 39.5 \%$, $5.4 \%$, and $20.54 \%$ for blood groups $A, B, A B$ and $O$,

Introduction

The word "blood group" refers to the antigens present on the red blood cell (RBC) surface. "Blood type"

a. Major Dr. Md. Soleman Badsha, Graded Specialist in Medicine, $\mathrm{CMH}$, Barishal

b. Col. Dr. Md. Mizanur Rahman Khan, MPH, MPhil, ADMS, 7 Div Hq, Shikh Hasina CMH, Barishal

c. Lt. Col. SM Belal Uddin, MPH, Commanding officer, $\mathrm{CMH}$, Barishal

d. Major Dr. Kamrun Nesa, Graded Specialist in Poediatries, CMH, Barishal

Adddress of Correspondence: Major Dr. Md. Soleman Badsha, Graded Specialist in Medicine, $\mathrm{CMH}$, Barishal, 506, West Nakhalpara, Sonar Tori (A-17 Flat), Jejgaon, Dhaka, Cell: 01769300200, E-mail: soleman.badsha@gmail.com respectively. Blood group $A$ was statistically significantly more frequent among those infected with COVID-19 compared to controls (34.6\% vs. $21.83 \%$, p-value 0.045 (<0.05); OR: 1.894). On the other hand, the frequency of blood group $O$ was significantly lower in the COVID-19 patients, compared to the control group (20.54\% vs $32.88 \%$, p-value0.049 (<0.05); OR: 0.528). Although there was a higher percentage distribution of the B blood group among COVID-19 patients as compared to the control groups, this difference did not reach statistical significance. Also, there was no significant difference in the risk of COVID-19 in blood group $A B$ with a distribution of $6.2 \%$ in control group, and5.4\% in COVID-19 patients.

Conclusion: The results of the present study suggest that the blood group $A$ might have a role in increased susceptibility to the COVID-19 infection and the blood group $O$ might be somewhat protective.

Keywords: ABO, Rh-D, Blood group system, COVID-19, SARS-CoV-2.

(J Bangladesh Coll Phys Surg 2021; 39: 94-99)

refers to a specific pattern of antigen-antibody reaction within a specified setting. Austrian Scientist Karl Landsteiner was the pioneer in describing the ABO blood group system in $1900^{1}$. O, A, and B types are the major blood groups. Due to the different frequency of different $\mathrm{ABO}$ blood types among various populations, the $\mathrm{ABO}$ blood groups appear to be important during evolution. The second most crucial antigen in blood transfusions is the rhesus-system ${ }^{2}$. An individual's RBC surface may or may not contains $\mathrm{Rh}$ or D-antigen; accordingly, Rh-positive (D-antigen present) or Rh-negative (D-antigen absent) blood group is indicated ${ }^{3}$. ABO antigens are expressed in several human tissues and cells, including epithelium, sensory neurons, platelets, and vascular endothelium. It is also simultaneously expressed as a surface molecule ${ }^{4,5}$. It 
is, therefore, no wonder that the clinical relevance of an $\mathrm{ABO}$ blood group reaches beyond the conventional frontiers of immune- hematological understanding, where the pathogenesis of a wide variety of human diseases, primarily cancers and infections cardiovascular disorders are involved. Non-O blood group reveals that the risk of venous thrombosis is roughly double ${ }^{6}$. The risk of overall mortality in non-O blood groups is comparatively higher from cardiovascular diseases when compared to individuals with the $\mathrm{O}$ blood groups ${ }^{7,8}$. In comparison with blood group $\mathrm{O}$, people with blood group $\mathrm{A}, \mathrm{AB}$, or $\mathrm{B}$ are vulnerable to develop pancreatic cancer ${ }^{9}$. The ABO phenotype relates to the severity of a number of infectious diseases. The severity of cholera infection (Vibrio cholerae strains $\mathrm{O} 1 \mathrm{El}$ Tor and O139) is the most prominent amongst the patients with $\mathrm{O}$ blood group ${ }^{10,11}$. It has been found that viral infections are linked to the ABO blood group. ABO blood group antigens may affect the vulnerability to Norwalk virus infection.[12] One study also found that blood group $\mathrm{O}$ has lower susceptibility to hepatitis B, C, HIV, syphilis or malaria $^{13}$

Corona virus disease 2019 (COVID-19) surfaced in the city of Wuhan located in China, at the end of 2019. This virus rapidly spread and caused the current global pandemic ${ }^{14}$. In Bangladesh up to August 4, 2020 there are 242102 COVID-19 patients with 3184 deaths ${ }^{15}$. Numerous risk factors for COVID-19 have been reported. An increase in the patient's age has become synonymous with a rise in the risk of developing complications and has demonstrated higher death rates. Various studies have concluded that the male gender is more at risk and show more severe complications ${ }^{16,17}$. Various comorbidities such as, inflammatory bowel disease $(\mathrm{IBD})^{18}$, pre-existing kidney disease $\mathrm{e}^{19}$, and diabetes mellitus ${ }^{20}$ are documented risk factors. A new school of thought and finding is indicative that certain blood groups are more susceptible to the COVID-19 infection in comparison to others. A study conducted by Zietz et al., in the New York-Presbyterian (NYP) group of facilities discovered that Blood group A was associated with increased odds of testing positive for COVID-19 (OR 1.338, 95\% CI [1.072-1.672], $\mathrm{p}=0.009$ ), while O blood groups were associated with decreased odds of testing positive (OR $0.804,95 \%$ CI [0.654-0.987], $\mathrm{p}=0.036)^{21}$. This study also follows previous research study on SARS-CoV-2 by
Ellinghaus et al. where they found that patients with blood type A have a higher risk than other blood groups (OR, 1.45;

95\% CI [1.20-1.75], $\mathrm{P}=0.000148$ ) and for blood group $\mathrm{O}$ when compared with the other blood groups (OR, 0.65; 95\% CI [0.53-0.79], $\mathrm{P}=0.0000106)^{22}$. Göker et al. reported that blood group A was (57\%) higher amongst the COVID-19 patients followed by the blood group $\mathrm{O}(24.8 \%)^{23}$.

The linkage and effects of blood groups have been hypothesized using different facts:

For example, blood groups are dictated by sugars, and coronaviruses in the cattle have surface proteins that bind to sugars. It might be of value to consider the extra sugar $\mathrm{N}$-acetyl galactosamine, on the surface of blood group A cells [24], possibly suggesting more pathogen contact. This sugar is missing on blood group $\mathrm{O}$ cells ${ }^{24}$.

SARS-CoV-2 replicates in respiratory and gastrointestinal epithelium ${ }^{25}$, that can synthesize A or $\mathrm{B}$ glycan antigens, depending on the phenotype. If the $\mathrm{S}$ protein of an $\mathrm{A}, \mathrm{B}$, or $\mathrm{AB}$ group induvial carries respective glycan antigens, it is possible that binding of the respective antibodies can block the interaction between $\mathrm{S}$ protein and ACE2, thereby offering complete or incomplete protection ${ }^{26}$. Thus, infectivity between ABO groups can presumably be predicted e.g. the virus produced in an individual with blood group B will be carrying antigen B and has a higher chance of infecting a person with blood group $\mathrm{B}$ or $\mathrm{AB}$, as compared to blood group $\mathrm{A}$ or $\mathrm{O}$. This can explain the least number of cases in blood group $\mathrm{O}$ that contains both antibody- $\mathrm{A}$ and antibody-B. It is also believed that once the infection is fully established, it then replicates in the individual's epithelial cells and thus exhibits that individual's antigen, rendering the individual's antibodies ineffective ${ }^{26}$.

Here, we investigated the relationship between the $\mathrm{ABO}$ blood group type and the susceptibility to COVID-19 in patients who reported to $\mathrm{CMH}$ Barishal.

\section{Methods:}

\section{Study Design and Participants}

This retrospective cohort study included confirmed COVID-19 patents of 14 years or older, irrespective of gender, who were admitted in CMH Barishal from June 4, 2020 to August 3, 2020. 


\section{Data Collection}

A confirmed case of Covid-19 was identified as a positive result for nasal and pharyngeal swab specimens in real-time reverse transcriptasepolymerase-chain-reaction (RT-PCR) assay.[27] Hospitalized, clinically suspected, total 556 cases were enrolled. RT-PCR confirmed patients (185) were the study cohort, and negative ones were comparator.Statistical Analysis

Statistical analysis was performed by using IBM, SPSS version 25. Standard descriptive and analytical statistics were used to analyze the data. Chi-square test was used to test for significant difference and $\mathrm{P}$-value $\leq 0.05$ was considered significant.

\section{Results:}

The blood group distribution of 185 patients diagnosed with PCR positivity as A, B, O, AB were $34.6 \%, 39.5 \%, 20.54 \%$ and $5.4 \%$ respectively. $\mathrm{Rh}(+)$ was $98.9 \%$ and $\mathrm{Rh}(-) \quad 1.1 \%$. The blood group distribution of remaining 371 individuals the comparison group as $\mathrm{A}, \mathrm{B}, \mathrm{O}, \mathrm{AB}$ were $21.83 \%$, $39.08 \%, 32.88 \%$ and $6.2 \%$, respectively. $\mathrm{Rh}(+)$ was $95.7 \%$ and Rh (-) was $4.3 \%$ (Table 1 ). When the test negative comparison group was compared to the COVID-19 patient group, it was observed that the COVID-19 infection rate was statistically significantly higher in those with blood group A (34.6\% vs. $21.83 \%$, p-value 0.045 ; OR: 1.894$)$. In terms of $\mathrm{Rh}$ blood group system, it was determined that $\mathrm{Rh}$ positivity was also associated with COVID-19 diagnosis but not at significant level ( $\mathrm{p}=$ 0.163 , OR: 4.040) (Table 1). It was observed that the blood group $\mathrm{O}$ was significantly lower in the COVID-19 patient group in comparison to the controls (20.54\% vs $32.88 \%$, p-value 0.049; OR: 0.528). Although there was a higher percentage distribution of the B blood group among COVID-19 patients as compared to the control groups, this

Table 1: Summary of COV+vs COV-comparison of individual blood types.

\begin{tabular}{|c|c|c|c|c|c|}
\hline Blood Group & $\begin{array}{c}\text { COV+ counts } \\
N=185\end{array}$ & $\begin{array}{c}\text { COV- counts } \\
\mathbf{N}=371\end{array}$ & OR & $95 \% \mathrm{CI}$ & P-value \\
\hline A & $\begin{array}{l}\text { A: } 64(34.60 \%), \\
\text { Other than A: } 121 \\
(65.4 \%)\end{array}$ & $\begin{array}{l}\text { A: } 81(21.83 \%), \\
\text { Other than A: } 290 \\
(78.17 \%)\end{array}$ & 1.894 & $(1.011-3.551)$ & .045 \\
\hline B & $\begin{array}{l}\text { B: } 73(39.5 \%) \text {, } \\
\text { Other than B: } 112 \\
(60.5 \%)\end{array}$ & $\begin{array}{l}\text { B: } 145(39.08 \%), \\
\text { Other than B: } 226 \\
(60.92 \%)\end{array}$ & 1.018 & $(.577-1.795)$ & 0.952 \\
\hline $\mathrm{O}$ & $\begin{array}{l}\text { O: } 38(20.54 \%), \\
\text { Other than O: } 147 \\
(79.46 \%)\end{array}$ & $\begin{array}{l}\text { O: } 122(32.88 \%), \\
\text { Other than O: } 249 \\
(67.12 \%)\end{array}$ & 0.528 & $(.278-1.001)$ & 0.049 \\
\hline $\mathrm{AB}$ & $\begin{array}{l}\text { AB: } 10(5.4 \%), \\
\text { Other than AB: } 175 \\
(94.6 \%)\end{array}$ & $\begin{array}{l}\text { AB: } 23(6.2 \%), \\
\text { Other than AB: } 348 \\
(93.8 \%)\end{array}$ & 0.864 & $(.263-2.834)$ & 0.809 \\
\hline $\mathrm{Rh}$ & $\begin{array}{l}\text { Rh D }+ \\
: 183(98.9 \%) \\
\text { Rh D- } \\
: 2(1.1 \%)\end{array}$ & $\begin{array}{l}\text { Rh D }+ \\
: 355(95.7 \%) \\
\text { Rh D- } \\
: 16(4.3 \%)\end{array}$ & 4.040 & $(.488-33.420)$ & 0.163 \\
\hline
\end{tabular}

$N=$ Number of individuals having the given blood type who have a recorded test (positive or negative) for $S A R S-C o V-2$, and reports percentages relative to all blood groups.

OR $=$ Odds ratio $(\mathrm{COV}+$ vs $\mathrm{COV}-)$.

95\% CI = Confidence interval on the OR. 
difference was not significant. Also, there was no significant difference in the risk of COVID-19 in blood group $\mathrm{AB}$ with a distribution of $6.2 \%$ in control group, and $5.4 \%$ in COVID-19 patients.

\section{Discussion:}

Numerous studies have been published to date on the relationship between blood groups and diseases. [29-32] These studies include hepatitis B, hepatitis C, HIV, West Nile Virus, SARS-CoV and SARS-CoV-2 viruses.[28,30,33] In all these studies raised an issue that some blood groups may be susceptible to viral infections and some groups may be protective. Although many models of this predisposition or protectionism have been established, the mechanism has not been fully elucidated and has been suggested as possible causes. Natural anti-blood group antibodies, particularly anti-A antibody, of the ABO system to block the interaction of SARS-CoV spike protein and angiotensin converting enzyme 2 may be considered as one of the reasons suggested.[34] Several studies investigated the relationship between the ABO blood groups and COVID-19 infection. The first study was conducted in China and it was published on March, 2020.[34] The second study was conducted in New York, USA, and published on April, 2020.[35] In our control group, we found that blood groups B $(39.08 \%)$ and $\mathrm{O}(32.88 \%)$ were the two most frequent blood groups which also follow the previous study about the general distribution of $\mathrm{ABO}$ and $\mathrm{Rh}$ blood group among the general population of Bangladesh where most frequent blood groups were B (39.8\%) and O (27.6\%).[36] In this study, we found that $\mathrm{ABO}$ blood groups displayed different association risks for the infection with SARS-CoV-2 resulting in COVID-19. Specifically, blood group A was associated with an increased risk whereas blood group $\mathrm{O}$ was associated with a decreased risk, thus demonstrating that the $\mathrm{ABO}$ blood type is a biomarker for differential susceptibility of COVID-19. These findings are consistent with similar risk patterns of $\mathrm{ABO}$ blood groups for other corona virus infection found in previous studies. For example, Cheng et al. reported that the SARS-CoV infection susceptibility in Hong Kong was differentiated by the ABO blood group systems.[30] The authors found that compared with non-O blood group hospital staff, blood group $\mathrm{O}$ hospital staff had a lower chance of getting infected.

\section{Our study has few limitations:}

First, sample size was small in case of both patient group (185) and control group (371). Second, severe or critical cases were not included in this study due to less availability.

\section{Conclusion:}

Considering all data we found that blood group A was statistically significantly more frequent among those infected with COVID-19 compared to controls On the other hand, the frequency of blood group $\mathrm{O}$ was significantly lower in the COVID-19 patients, compared to the control group. The findings in the present study would have several potential clinical implications. 1) People with blood group A might need particularly strengthened personal protection to reduce the chance of infection; 2) It might be helpful to introduce $\mathrm{ABO}$ blood typing in the evaluation of SARS-CoV-2 infection; 3) blood group A may get priority in SARS COV-2 vaccine. However, the SARS-CoV-2 situation is evolving rapidly, and discoveries and anomalies are being reported daily. Therefore, it is advised to have more researches in this field before the blood groups added to the list is added as a risk factor for SARS-CoV-2 infection.

\section{References:}

1. Owen R. Karl Landsteiner and the first human marker locus. Genetics. 2000; 155(3):995-8.

2. Westhoff CM. The Rh blood group system in review: a new face for the next decade. Transfusion. 2004; 44(11):1663-73.https://doi.org/10.1111/j.0041-1132. 2004.04237.x, PMid:15504174

3. Mitra R, Mishra N, Rath GP. Blood groups systems. Indian J Anaesth. 2014; 58(5):524-8. https://doi.org/ 10.4103/0019-5049.144645,PMid:25535412 PMCid:PMC4260296

4. Franchini M, Liumbruno GM. ABO blood group: old dogma, new perspectives. ClinChem Lab Med. 2013; 51(8):1545-53. https://doi.org/10.1515/cclm-20130168, PMid:23648637

5. Liumbruno GM, Franchini M. Beyond immunohaematology: the role of the $\mathrm{ABO}$ blood group in human diseases. Blood Transfuse. 2013; 11(4):491-9.

6. Dentali F, Sironi AP, Ageno W, Turato S, Bonfanti C, Frattini F, et al. Non-O blood type is the commonest genetic risk factor for VTE: results from a meta-analysis of the literature. SeminThrombHemost. 2012; 38(5):535-48. https://doi.org/10.1055/s-00321315758, PMid:22740183 
7. Etemadi A, Kamangar F, Islami F, Poustchi H, Pourshams A, Brennan P, et al. Mortality and cancer in relation to $\mathrm{ABO}$ blood group phenotypes in the Golestan Cohort Study. BMC Med. 2015; 13:8. https://doi.org/10.1186/s12916-014-0237-8 PMid:25592833 PMCid:PMC4295491

8. Guo T, Fan Y, Chen M, Wu X, Zhang L, He T, et al. Cardiovascular Implications of Fatal Outcomes of Patients With Coronavirus Disease 2019 (COVID-19) [published online ahead of print, 2020 Mar 27]. JAMA Cardio.2020; e201017. https://doi.org/ 10.1001/jamacardio.2020.1017, PMid:32219356 PMCid:PMC7101506

9. Wolpin BM, Chan AT, Hartge P, Chanock SJ, Kraft $\mathrm{P}$, Hunter DJ, et al. ABO blood group and the risk of pancreatic cancer. J Natl Cancer Inst. 2009; 101(6):424-31. https://doi.org/10.1093/jnci/djp020 PMid:19276450 PMCid:PMC2657095

10. Rowe JA, Handel IG, Thera MA, Deans AM, Lyke $\mathrm{KE}$, Kone $\mathrm{A}$, et al. Blood group $\mathrm{O}$ protects against severe Plasmodium falciparum malaria through the mechanism of reduced rosetting. ProcNatlAcadSci U S A. 2007;104(44):17471-6. https://doi.org/10.1073/pnas. 0705390104, PMid:17959777 PMCid:PMC2077280

11. Harris JB, Khan AI, LaRocque RC, Dorer DJ, Chowdhury F, Faruque ASG, et al. Blood group, immunity, and risk of infection with Vibrio cholerae in an area of endemicity. Infect Immun. 2005; 73(11):7422-7, https://doi.org/10.1128/ IAI.73.11.74227427.2005, PMid:16239542 PMCid:PMC1273892

12. Lindesmith, L., Moe, C., Marionneau, S. et al. Human susceptibility and resistance to Norwalk virus infection. Nat Med 9, 2003; 548-553. https://doi.org/ 10.1038/nm860, PMid:12692541

13. Batool Z., Durrani S.H., Tariq S. Association of ABO and Rh Blood Group Types to Hepatitis B, Hepatitis C, HIV and Syphillis Infection, a Five Year' Experience in Healthy Blood Donors in a Tertiary Care Hospital. Journal of Ayub Medical College Abbottabad. 2017; 29, 90-92. http://jamc.ayubmed.edu.pk/ index.php/jamc/article/view/1729/874

14. Guo YR, Cao QD, Hong ZS, Tan YY, Chen SD, Jin $\mathrm{HJ}$, et al. The origin, transmission and clinical therapies on coronavirus disease 2019 (COVID-19) outbreak - an update on the status. Mil Med Res. 2020; 7(1):11. https://doi.org/10.1186/s40779-020-00240-0 PMid:32169119 PMCid:PMC7068984

15. WHO Coronavirus Disease (COVID-19) Dashboard. [Accessed 27/06/2020] Available from, https://covid19.who.int/

16. Nikpouraghdam M, Farahani AJ, Alishiri G, Heydari S, Ebrahimnia M, Samadinia H, et al. Epidemiological characteristics of coronavirus disease 2019
(COVID-19) patients in IRAN: A single center study. J ClinVirol. 2020; 127:104378. https://doi.org/ $10.1016 / j . j c v .2020 .104378$,PMid:32353762 PMCid:PMC7172806

17. Anastassopoulou C, Russo L, Tsakris A, Siettos C. Data-based analysis, modelling and forecasting of the COVID-19 outbreak. PLoS One. 2020 https://doi.org/ 10.1101/2020.02.11.2002218615(3):e0230405. Published 2020 Mar 31.

18. Fiorino G, Allocca M, Furfaro F, Gilardi D, Zilli A, Radice S, et al. Inflammatory bowel disease care in the COVID-19 pandemic era: the Humanitas, Milan experience [published online ahead of print, $2020 \mathrm{Mar}$ 24]. J Crohns Colitis.2020; jjaa058. https://doi.org $10.1093 /$ ecco-jcc/jjaa058,PMid:32211765 PMCid:PMC7184487

19. Banerjee D, Popoola J, Shah S, Ster IC, Quan V, Phanish M. COVID-19 infection in kidney transplant recipients. Kidney Int. 2020; 97(6):1076-82. https://doi.org/10.1016/j.kint.2020.03.018 PMid:32354637 PMCid:PMC7142878

20. Guo W, Li M, Dong Y, Zhou H, Zhang Z, Tian C, et al. Diabetes is a risk factor for the progression and prognosis of COVID-19 [published online ahead of print, 2020 Mar 31]. Diabetes Metab Res Rev. 2020; e3319.https://doi.org/10.1002/dmrr.3319 PMCid:PMC7228407

21. Zietz M, Tatonetti NP. Testing the association between blood type and COVID-19 infection, intubation, and death.MedRxiv; 2020. https://doi.org/10.1101/2020.04.08.20058073

22. Ellinghaus D, Degenhardt F, Bujanda L, Buti M, Albillos A, Invernizzi $\mathrm{P}$, et al. Genomewide Association Study of Severe Covid-19 with Respiratory Failure[published online ahead of print, 2020 Jun 17]. New England Journal of Medicine. 2020

23. Göker H, Aladağ-Karakulak E, Demiroğlu H, Ayaz CM, Büyükaşik Y, İnkaya AC, et al. The effects of blood group types on the risk of COVID-19 infection and its clinical outcome [published online ahead of print, 2020 Jun 4]. Turk J Med Sci. 2020 https://doi.org/10.3906/sag-2005-395 PMid:32496734 PMCid:PMC7379446

24. Cooling L. Blood groups in infection and host susceptibility. ClinMicrobiol Rev 2015;28(3):801-70. https://doi.org/10.1128/CMR.00109-14 PMid:26085552 PMCid:PMC4475644

25. Belser J. Assessment of SARS-CoV-2 replication in the context of other respiratoryviruses. Lancet Respir Med 2020. https://doi.org/10.1016/ S2213-2600 (20)30227-7 
26. Yamamoto. Fumiichiro.ABO blood groups and SARS-CoV-2 infection. Research gate Presentation 2020/03/26. https://doi.org/10.13140/RG.2.2.24833.20329

27. Tahamtan A and Ardebili A. Real-Time RT-PCR in COVID-19 Detection: Issues Affecting the Results. Expert Review of Molecular Diagnostics 2020; 20, 453-454. https://doi.org/10.1080/14737159.2020.1757437 PMid:32297805 PMCid:PMC7189409

28. Zhao J, Yang Y, Huang H, Li D, Gu D, Lu X, et al. Relationship between the $\mathrm{ABO}$ blood group and the COVID-19 susceptibility. medRxiv 2020. https://doi.org/10.1101/2020.03.11.20031096

29. Araç E, Solmaz I. Evaluation of blood groups in patients with anti TPO positive. Asian J Med Sci 2019; 10: 67-70. https://doi.org/10.3126/ ajms.v10i6.25878

30. Cheng Y, Cheng G, Chui CH, Lau FY, Chan PK, Ng $\mathrm{MH}$, et al. $\mathrm{ABO}$ blood group and susceptibility to severe acute respiratory syndrome. JAMA. 2005 Mar 23; 293(12):1450-1. doi: 10.1001/jama.293.12.1450-c https://doi.org/10.1001/jama.293.12.1450-c

31. Anstee DJ. The relationship between blood groups and dis $\neg$ ease. Blood 2010; 115: 4635-4643. https://doi.org/10.1182/blood-2010-01-261859 PMid:20308598

32. Teshome Y, Mekonen W, Birhanu Y, Sisay T. The association between $\mathrm{ABO}$ blood group distribution and peptic ulcerdis $\neg$ ease: a cross-sectional study from Ethiopia. J Blood Med 2019; 10: 193-197. https://doi.org/10.2147/JBM.S209416 PMid:31308778 PMCid:PMC6613600

33. Kaidarova Z, Bravo MD, Kamel HT, Custer BS, Busch MP, Lanteri MC, et al. Blood group A and D negativity are associated with symptomatic West Nile virus infection. Transfusion 2016; 56: 1699-1706. https://doi.org/10.1111/trf.13622 PMid:27189860 PMCid:PMC4938756

34. Guillon P, Clement M, Sebille V, Rivain JG, Chou $\mathrm{CF}$, Clouet NR, et al. Inhibition of the interaction between the SARS-CoV spike protein and its cellular receptor by anti-histo-blood group antibodies. Glycobiology 2008;18(12):1085-93. https://doi.org/10.1093/glycob/cwn 093 PMid:18818423 PMCid:PMC7108609

35. Zietz M, Zucker JE, Tatonetti NP. Testing the Association between Blood Type and COVID-19 Infection, Intubation, and Death.medRxiv 2020. https://doi.org/10.1101/2020.04.08.20058073

36. Sultana, Rayhana, Rahman, Zaida, Helali, Asadul, et al. Study of abo and RH-D blood groups among the common people of capital city of Bangladesh. International Journal of Pharmacy and Pharmaceutical Sciences 2013; 5.814-816. https://www.researchgate.net/ publication/255822982 